\title{
Correction to: Cladribine Tablets: A Review in Relapsing MS
}

\author{
Emma D. Deeks ${ }^{1}$
}

Published online: 30 January 2019

c) Springer Nature 2019

\section{Correction to: CNS Drugs (2018) 32(8):785-796 https://doi.org/10.1007/s40263-018-0562-0}

The article Cladribine Tablets: A Review in Relapsing MS, written by Emma D. Deeks, was originally published Online First without open access. After publication in volume 32, issue 8, pages 785-796, Merck KGaA requested that the article be Open Choice to make the article an open access publication. Post-publication open access was funded by Merck KGaA. The article is forthwith distributed under the terms of the Creative Commons Attribution-NonCommercial 4.0 International License (http://creativecommons.org/ licenses/by-nc/4.0/), which permits any noncommercial use, duplication, adaptation, distribution and reproduction in any medium or format, as long as you give appropriate credit to the original author(s) and the source, provide a link to the Creative Commons license and indicate if changes were made.

The original article has been corrected.

OpenAccess This article is distributed under the terms of the Creative Commons Attribution-NonCommercial 4.0 International License (http://creativecommons.org/licenses/by-nc/4.0/), which permits any noncommercial use, distribution, and reproduction in any medium, provided you give appropriate credit to the original author(s) and the source, provide a link to the Creative Commons license, and indicate if changes were made.
Emma D. Deeks

demail@springer.com

1 Springer, Private Bag 65901, Mairangi Bay, Auckland 0754, New Zealand 